\title{
Priorities in policy and management when existing biodiversity stressors interact with climate-change
}

\author{
Don A. Driscoll • Adam Felton • Philip Gibbons • \\ Annika M. Felton • Nicola T. Munro • \\ David B. Lindenmayer
}

Received: 14 December 2009 / Accepted: 9 July 2011

(C) Springer Science+Business Media B.V. 2011

\begin{abstract}
There are three key drivers of the biodiversity crisis: (1) the well known existing threats to biodiversity such as habitat loss, invasive pest species and resource exploitation; (2) direct effects of climate-change, such as on coastal and high elevation communities and coral reefs; and (3) the interaction between existing threats and climate-change. The third driver is set to accelerate the biodiversity crisis beyond the impacts of the first and second drivers in isolation. In this review we assess these interactions, and suggest the policy and management responses that are needed to minimise their impacts. Renewed management and policy action that address known threats to biodiversity could substantially diminish the impacts of future climate-change. An appropriate response to climate-change will include a reduction of land clearing, increased habitat restoration using indigenous species, a reduction in the number of exotic species transported between continents or between major regions of endemism, and a reduction in the unsustainable use of natural resources. Achieving these measures requires substantial reform of international, national and regional policy, and the development of new or more effective alliances between scientists, government agencies, non-government organisations and land managers. Furthermore, new management practices and policy are needed that consider shifts in the geographic range of species, and that are responsive to new information acquired from improved research and monitoring programs. The interactions of climate-change with existing threats to biodiversity have the potential to drive many species to extinction, but there is much that can be done now to reduce this risk.
\end{abstract}

D. A. Driscoll $(\bowtie) \cdot$ A. Felton $\cdot$ P. Gibbons $\cdot$ A. M. Felton $\cdot$ N. T. Munro $・$ D. B. Lindenmayer Fenner School of Environment and Society, Australian National University,

Canberra, ACT 0200, Australia

e-mail: don.driscoll@anu.edu.au

Present Address:

A. Felton - A. M. Felton

Southern Swedish Forest Research Centre, Swedish University of Agricultural Sciences, Box 49, SE-230 53 Alnarp, Sweden 


\section{Introduction}

Biodiversity on earth is in crisis with an unprecedented loss of species (Butchart et al. 2010; Conrad et al. 2006; Laurance 2007; Mooney 2010; Sala et al. 2000; Wake and Vredenburg 2008). Through direct and indirect human activities, species extinction rates are far higher than the background rate of extinction (McCallum 2007; Pimm et al. 2006; Pimm and Raven 2000). There are several main causes of ongoing species extinctions (Lande 1998; Sala et al. 2000; Vitousek et al. 1997), including habitat loss (Pitman et al. 2002), invasive species (Duncan and Blackburn 2004) and resource exploitation (Burgman et al. 2007), although climate change is expected to become more important in coming decades (e.g. Sekercioglu et al. 2008).

Climate-change has now become a major focus of the media (Boykoff 2007) and governments, with dedicated policies and portfolios developed to deal with this major environmental threat (Buhrs 2008; Pyke et al. 2008). Climate-change may have recently surpassed all other environmental causes in terms of public profile (Novacek 2008) with evidence from North America that the majority of people are concerned about climate-change impacts, but are far less concerned about other biodiversity conservation issues (LindemannMatthies and Bose 2008; Semenza et al. 2008). Other threats to biodiversity have apparently waned in importance from a public and government perspective (Buhrs 2008; Novacek 2008).

Despite popular opinion, climate-change alone may not be the greatest near-term threat to biodiversity (Lewis 2006; Sala et al. 2000; Secretariat of the Convention on Biological Diversity 2010). In this paper, we argue there are three key drivers of the biodiversity crisis. First are the well understood and globally important threats to biodiversity such as habitat loss and fragmentation, invasive species and resource exploitation. Second, climate-change resulting from increased greenhouse gases in the atmosphere directly threatens some species with extinction, such as corals, coastal specialists and species confined to high elevations (Desantis et al. 2007; Hoegh-Guldberg et al. 2007; Nogue et al. 2009; Parmesan 2006; Wake and Vredenburg 2008). The third driver is the interactions and synergisms between the first two. That is, the combined effects of changing climate and existing threats to biodiversity will multiply the impacts that those processes would have alone, thereby significantly magnifying the biodiversity crisis (Brook et al. 2008; Keith et al. 2008; Sala et al. 2000).

In this paper, our intention is to succinctly review the extent of interaction of climate change with three globally important causes of biodiversity loss: native vegetation loss and fragmentation, invasive species, and resource exploitation. Our first major aim is to enable people working across the broad range of climate-change related fields to understand why these key threats to biodiversity are inextricably also part of the climate-change phenomenon, and therefore why reducing these threats must feature in adaptation measures to climate change. While much effort is already expended countering existing threats to biodiversity, climate-change adaptation now demands new and more efficient approaches, because current efforts in many cases are inadequate.

A major shortcoming of recent climate-change impact studies is that suggested actions do not specifically identify the situations in which a solution may work or who should implement it (Felton et al. 2009; Heller and Zavaleta 2009). The second aim of our paper is therefore to collate well-substantiated and empirically based recommendations from the literature to identify a concise list of the most important actions, policy changes, and players needed to support climate-change adaptation. In doing so, we highlight substantial shortcomings in international, national and regional policy that require urgent attention, in addition to challenges that must be overcome for new scientific approaches to transfer to the policy and decision-making realm. 


\section{Native vegetation loss and fragmentation interacts with climate-change}

Approximately 13 million ha of the world's natural forests are cleared annually (FAO 2005). Land clearing is not only one of the greatest contemporary threats to terrestrial biodiversity, but also one of the greatest threats compounding the impact of climate-change on biota (Millennium Ecosystem Assessment 2005; Sala et al. 2000; Theurillat and Guisan 2001). There are three principal ways that clearing native vegetation may exacerbate climatechange impacts on biodiversity.

First, clearing native vegetation for agriculture or forestry exacerbates climate-change because it is a major source of greenhouse gas emissions world-wide (Gullison et al. 2007). Taking into account reafforestation, Houghton (2003) reported that logging, land clearing and agriculture released 2.2 Pg of carbon per year during the 1990s, which is approximately one third of the amount released by burning fossil fuels (Houghton 2007). Although estimating the amount of carbon released by land clearing remains difficult (Ramankutty et al. 2007), recent figures suggest that forest loss, degradation and loss of peat habitats accounts for 8-20\% of anthropogenic greenhouse gas emissions (van der Werf et al. 2009).

A second way that clearing native vegetation strengthens the impacts of climate-change is through its direct influence on regional climates (Deo et al. 2009; McAlpine et al. 2007; McAlpine et al. 2009). Land clearing can increase regional temperature, reduce rainfall and increase weather variability (McAlpine et al. 2007). This increase in extreme weather could compound similar trends in some parts of the globe that are predicted to result from increased atmospheric greenhouse gases (Los et al. 2006; McAlpine et al. 2007).

Third, habitat modification, loss and fragmentation can prevent species from dispersing between remaining habitat patches (Soulé et al. 2004). The resulting reduction and fragmentation of populations interacts with climate-change to magnify the risk of extinction that species face if confronted with just one of these threatening processes (Opdam and Wascher 2004; Travis 2003). A dangerous interaction between fragmentation and climatechange may arise when a fragmented landscape (1) hinders dispersal, preventing species from tracking their climatic niche (Hill et al. 2001; Marini et al. 2009; Primack and Miao 1992), (2) offers a reduced availability of habitat situated in suitable climate space (Huntley 1999; Vos et al. 2008), and (3) harbors small populations which generally possess lower genetic diversity, limiting the potential for adaptation to changing climate (Jump and Penuelas 2005). Dispersal-limited species will be particularly vulnerable to these mechanisms (Thomas et al. 2004; Thuiller et al. 2006).

In summary, given the compounding negative effects of climate-change and habitat loss on biodiversity, there is an opportunity to substantially ameliorate climate-change impacts by conserving and re-establishing native vegetation (Bekessy and Wintle 2008).

\subsection{Policies to reduce land clearing}

Reducing the area cleared is the most important action to take, because this avoids the extensive difficulties and time needed to effectively restore otherwise degraded habitats (Secretariat of the Convention on Biological Diversity 2010). Actions to address the primary drivers of land clearing should be part of any effective land clearing policy (Lambin et al. 2001). At the most fundamental level, actions to reduce per-capita consumption and population growth are required to reduce demand to clear more land (Ehrlich and Holden 1974), although this is a long-term solution. However, as discussed by Lambin et al. (2001), it is simplistic to link land clearing to per-capita consumption and population growth alone. Land clearing continues at rapid rates in different regions for a range of reasons, which is perhaps why Kishor and Belle 
(2004) found very few socio-economic variables significantly associated with land clearing across a dataset spanning 90 countries.

In general, strong governance, such as rule of law, control of corruption, government effectiveness, accountability and political stability (Kaufmann et al. 1999), is an underlying requirement for effective land clearing policy (Gaveau et al. 2009; Kishor and Belle 2004). Within a framework of good governance, a range of national-level financial incentives that promote clearing are important to redress. For example, perverse systems of carbon accounting have provided incentives to clear native vegetation prior to the establishment of carbon sinks or biofuel plantations (Lindenmayer 2009; Pineiro et al. 2009; Schulze et al. 2003), problems that could be quickly eliminated through national regulation, and promoted through international agreements (van Oosterzee et al. 2010).

Land clearing could potentially be decoupled from economic and population growth by improving access to knowledge and technology. Green et al. (2005) observed an approximate doubling in agricultural production from 1960 to 2000 in developed countries despite a slight reduction in the area under production. This was due to improvements in, among others, plant and animal breeding, the use of fertilizer and irrigation. This can have benefits for biodiversity if it reduces the rate of clearing for agricultural development (Ewers et al. 2009; Green et al. 2005). However, the positive effects on biodiversity of focussing agricultural production in a limited area are tempered for several reasons. Intensifying agriculture can be associated with removal of key habitat features at the farmscale (such as scattered trees, Fischer et al. 2010; Manning et al. 2006). Off-site impacts from agriculture can increase with intensification (e.g. due to run-off of agricultural chemicals), so increasing the efficiency of agricultural inputs must be part of a solution based on intensifying agriculture (Tilman 1999). Further, the intensification of agricultural production is not always offset by land sparing, or a reduction in the net area cleared for agriculture (Ewers et al. 2009). Thus, there must be policy settings that link land sparing with agricultural intensification.

While traditional command and control regulation has a role to play in any effective land clearing policy (Binswanger 1991; Gaveau et al. 2009), mixed success with regulation and enforcement (Borner and Wunder 2008; Kishor and Belle 2004; Tomich et al. 2004) has seen the recognition of other policy approaches to reduce land clearing, such as marketbased instruments and financial incentives to protect native vegetation (Ring et al. 2010). Biodiversity offsets is a market-based instrument that has been employed in many countries to reduce the impacts on biodiversity of land clearing (ten Kate et al. 2004). Regulators impose a "cap" on biodiversity loss, and developments can proceed only if any loss of biodiversity can be offset with actions undertaken elsewhere. However, biodiversity offsets deliver no net loss in a narrower range of circumstances than the policy is typically applied (Gibbons and Lindenmayer 2007). Gibbons and Lindenmayer (2007) suggested that offsets will deliver no-net-loss in biodiversity only if: (a) clearing is restricted to highly modified habitats or habitats that will not persist irrespective of pressure to clear, (b) any temporary loss between clearing and the maturation of the offset does not represent a significant risk to biota (see also, Bekessy et al. 2010), (c) gains are sufficient to offset losses, (d) precaution and adaptive management are applied and (e) there is adequate compliance. Thus, biodiversity offsets can only be applied in regions with a governance structure that permits regulation, enforcement and a commitment to no net-loss of biodiversity.

Land clearing also could be effectively reduced at a national or regional level using a carbon trading or taxing system, and, in a kind of global offsets market, using REDD or related mechanisms (Reduced Emissions from Deforestation and forest Degradation, Ebeling and Yasue 2008; Kindermann et al. 2008). REDD is formulated to use market and 
financial incentives to reduce the emissions of greenhouse gases from deforestation and forest degradation in developing countries. REDD would principally involve monetary payments from developed nations to those developing nations possessing large forest carbon stocks otherwise vulnerable to land clearance. It provides a framework for what is potentially the fastest and least expensive means for reducing global greenhouse gas emissions (Strassburg et al. 2009). However, careful planning is needed to ensure that both reduced emissions and biodiversity conservation goals are met (Corbera et al. 2010; Venter et al. 2009). A modification of REDD, known as REDD+, is an important step towards achieving positive social and biodiversity outcomes in addition to carbon sequestration (Campbell 2009). However, implementing REDD + will require substantial commitment by collaborating governments and non-government agencies to improving data collection, developing appropriate governance and building adequate operational capacity (Burgess et al. 2010). This suite of actions would lead to immediate reductions in the severity and extent of the interaction of climate change with habitat loss.

\subsection{Policies to support restoration}

Large-scale restoration of native vegetation and the re-establishment of large-scale connectivity is recognised as an essential response to the biodiversity crisis (Gatewood 2003; Jackson and Hobbs 2009; Soulé et al. 2004) and is the most frequently recommended action to counter climate-change impacts on biodiversity (reviewed by Heller and Zavaleta 2009). Effective policy to support the long-term goal of restoration would direct resources for restoration into priority regions, ensure appropriate species are used in restoration programs and link carbon sequestration projects to biodiversity outcomes.

Strategic location of restoration or habitat retention will be an important new approach under climate-change. Restricted-range species are those most likely to be threatened if their movement and dispersal is blocked by habitat loss (Carvalho et al. 2010; Hughes et al. 1996; Steffen et al. 2009; Westoby and Burgman 2006). Therefore, priority areas for conservation action are those likely to be colonised by species with small geographic ranges as a result of climatic shifts. Modelling methods are being developed to help identify priority regions (e.g. Carvalho et al. 2010). Such tools must now be refined and adapted by governments and non-government organisations that are charged with funding, planning and undertaking restoration. The alternative, of haphazardly located restoration, is unlikely to lead to the best conservation investment (Hodgson et al. 2009). Translating prioritization modelling into policy and management will require deliberate effort by scientists, policy makers and managers to bridge the research-policy divide (Anon. 2007).

After regions have been strategically prioritised for restoration, populations of species to be restored must be carefully considered. To avoid introducing new environmental weeds, restoration could use local native species, including individuals from multiple source populations to maximise adaptive potential (Lawler 2009). However, there is concern that shifting climatic niches may render local species less suited for restoration than species from further afield (Hobbs et al. 2009). Introducing species that did not naturally occur in a region in an attempt to pre-empt shifting environmental niches is a risky strategy (Heller and Zavaleta 2009) and there are doubts as to whether it is possible to adequately assess those risks (Ricciardi and Simberloff 2009a, b). Although many translocated species may not become invasive, some intra-continental translocations have had substantial impacts (Mueller and Hellmann 2008), and the enormous impacts of translocations between continents are well known (see section below on Invasive exotic species). Given the poor understanding of the risk that translocated species may become invasive, but the knowledge 
that invasive species can have very large impacts on biodiversity, assisted migration of nonnative species cannot be widely adopted as a routine adaptation measure (Fazey and Fischer 2009; Ricciardi and Simberloff 2009b). National or regional policy and management plans for restoration should reflect this uncertainty.

Nevertheless, there are compelling cases where species are likely to become extinct without ex-situ conservation measures (Rull et al. 2009; Vitt et al. 2010; Williams et al. 2003), and assisted migration may be an important option to consider (Hoegh-Guldberg et al. 2008; Richardson et al. 2009). Hoegh-Guldberg et al. (2008) provided a decision framework to identify cases where translocations are justified. Within that framework, transparent decision-support methods need to be developed and applied (Richardson et al. 2009), requiring close collaboration of scientists and managers. Restoration policy should consider translocations on a species-by-species basis, with translocations justified when there is a high risk of extinction in-situ, when translocation is feasible, and when the benefits outweigh biological and socio-economic costs (Hoegh-Guldberg et al. 2008). Obtaining knowledge about risks and feasibility will require new targeted research (McLachlan et al. 2007).

The third policy response to support habitat restoration makes the link between biodiversity conservation and carbon sequestration. There are great benefits to climate change adaptation of using carbon-sink plantings in a way that enhances biodiversity conservation (Arnalds 2004; Bekessy and Wintle 2008; Lindenmayer 2009; Plantinga and $\mathrm{Wu}$ 2003). Policies to subsidize plantings, with the aim to draw carbon from the atmosphere, are now common in many countries (Heath and Joyce 1997; Kula 2010; Zhao and Wen 2010). However, such policies would have greater climate-change adaptation potential if they encouraged biodiversity conservation alongside carbon sequestration (Bekessy and Wintle 2008). Currently, opportunities for conserving biodiversity while storing carbon in vegetation are being lost because national, regional and international policy settings linking carbon and biodiversity are often inappropriate and revisions are urgently needed (Dwyer et al. 2009; Haskett et al. 2010; van Oosterzee et al. 2010).

\subsection{Risks of perverse outcomes}

With new policy directions, there are new risks of perverse biological outcomes that must be guarded against or removed. What we mean by perverse outcomes are, for example, when native vegetation is cleared to establish carbon sinks, or if exotic species used for revegetation become invasive or alter fire or hydrological processes (Lindenmayer 2009). There are already many examples of revegetation using exotic species which now pose an invasive threat (e.g. Costa et al. 2004; Firth et al. 2006; Harwood et al. 1997; Kotiluoto et al. 2009; Ren et al. 2009), and there are further examples of plans to spread exotic species in an attempt to sequester carbon (e.g. Velez and Del Valle 2007). We suggest that a strong, rapid policy and management response is needed to prevent perverse outcomes of misguided revegetation and carbon sequestration programs.

\section{Invasive exotic species and climate-change}

Causally related to current global mass extinctions (Pimm et al. 2006) is an accelerating mass invasion event that is several orders of magnitude above prehistoric rates of species range expansion (Ricciardi 2007; Thomas and Ohlemüller 2009). The increasing rate of invasion of non-native species, especially those that traverse continents or move between 
major areas of endemicity, is a key endangering process for many species (Mack et al. 2000; Pimentel et al. 2005). Invasive exotic vertebrates (Short and Smith 1994), invertebrates (Snyder and Evans 2006), plants (D'Antonio and Vitousek 1992) and diseases (Rachowicz et al. 2005) have taken an enormous toll on native species. Globally, invasive exotic species cost billions of dollars annually to manage, with these costs set to rise as additional species arrive in new regions (McNeely et al. 2001; Xu et al. 2006).

Climate-change is expected to exacerbate problems arising from invasive exotic species (Dukes and Mooney 1999; McNeely et al. 2001; Mooney and Hobbs 2000). Impacts include an increased rate of spread of invasive plants during more frequent extreme weather events (Truscott et al. 2006; Zapiola et al. 2008) and increased competitive ability of invasive plants with increasing $\mathrm{CO}_{2}$ concentrations (Smith et al. 2000). There is also evidence for increased virulence of pathogens at high latitudes or elevation due to increased temperatures (Laurance 2008; Rahel and Olden 2008; Wake and Vredenburg 2008) and increased sources of invasive species as farming expands into regions previously too cold (Rahel and Olden 2008). There is a risk that mechanisms of introduction will change, particularly through accidental transport and changed patterns of international trade, and there is a risk that current control methods may become less effective (Hellmann et al. 2008). Although not all regions will be equally affected by invasive exotic species (RouraPascual et al. 2004), and newly arrived species may provide environmental benefits if they fill vacant niches (Thomas and Ohlemüller 2009), on balance, the interactions of invasive species with climate-change are likely to increase the threat of extinction to native species (Parmesan 2006; Ward and Masters 2007). This is particularly the case with regards to species movements between continents and between centres of endemism (Thomas and Ohlemüller 2009) where there is a strong history of species extinctions (Duncan and Blackburn 2004; Short and Smith 1994).

\subsection{Preventing arrival of new invasive species}

Given the increased impacts of invasive exotic species that are expected with climatechange, adaptation to climate-change is contingent on better management of invasive species than has been achieved to date. Preventing further introductions is the cheapest and most effective step towards managing invasive exotic species (Keller et al. 2007; Mack et al. 2000; McNeely et al. 2001). Managing the routes by which invasive species enter a new region will be particularly important (Hulme 2009; Hulme et al. 2008). Many invasion routes have substantial industries supporting them. For example, the livestock grazing industry imported and continues to spread exotic grasses in many regions of the world (Bortolussi et al. 2005; D'Antonio and Vitousek 1992; Nichols et al. 2006). Trees introduced for forestry, carbon sequestration or biofuels invade native vegetation and can have substantial impacts on native communities (Becerra and Bustamante 2008; Fine 2002; Pyke et al. 2008; Richardson 1998). The horticulture industry is a major source of invasive plant species and some animals (Goulson 2003; Hingston et al. 2002). For example, in Australia, 70\% of invasive weeds are garden escapes and many are still available for sale (Groves et al. 2005). In Mediterranean regions, dry-adapted garden plants posed the greatest risk of becoming invasive (Marco et al. 2010). The pet trade is a fourth major source of invasive exotic species globally (Copp et al. 2007; Lockwood 1999; Rixon et al. 2005). Whittington and Chong (2007) point out that over one billion ornamental fish are traded annually, often resulting in accidental or deliberate introductions and establishment.

The routes of introduction imply that more effort is needed to resolve the conflict between the economic interests of those who import and spread exotic species and human 
communities who usually bear the cost of invasive species impacts and control (Buckley 2008; Cook and Fraser 2008; Cook et al. 2010). Under the World Trade Organisation (WTO) agreement on Sanitary and Phytosanitary Measures, a country may preclude importation of a new species if there is adequate evidence that it will impact on human, plant or animal life or health. However, this mechanism has limited scope for excluding species or preventing accidental introductions due to contention over what constitutes adequate evidence (Pharo 2006) and because there are political and financial incentives to reduce trade barriers (McNeely et al. 2001). A decade after McNeely et al. (2001) urged resolution of WTO-sponsored invasive alien species, there remains a need for greater international regulation of the risk of spreading invasive alien species through trade (Perrings et al. 2010). Substantial engagement in international negotiations is required to achieve this, including by changing WTO conventions (Cook et al. 2010), and by making better use of links between the WTO and other international conventions, such as the Convention on Biological Diversity (Kahn and Pelgrim 2010; McNeely et al. 2001). Altering these international policy settings would have immediate benefits for conservation in the face of climate change by substantially reducing the rate of arrival of new potentially invasive species.

Besides international agreements, national policy also can have a substantial impact. For example, policies that remove incentives to import raw rather than processed goods could reduce the risk of invasive species arriving accidently in unprocessed materials (Tu et al. 2008). This could involve application of lower tariffs for processed goods compared with raw goods (Tu et al. 2008) (although this may impinge on WTO agreements). Improved quarantine measures are another important step that national governments can take. Effective biosecurity screening is an essential component of climate change adaptation. Current systems are inadequate for identifying potentially invasive species or to prevent accidental introductions. Substantial institutional changes to improve biosecurity are thus needed (Cook et al. 2010; Jefferson et al. 2004; Keller et al. 2007; Mack 1996; McNeely et al. 2001), which in Europe, includes establishment of a new multi-national co-ordinating institution (Hulme et al. 2009). A range of additional national-level approaches to reducing threats from invasive alien species was canvassed by McNeely et al. (2001). Although that work was completed ten years ago, it remains a comprehensive policy guide for adaptation that will quickly reduce the interaction of alien invasive species with climate change.

\subsection{Managing established invasive alien species}

Management of invasive species that are already established will continue to be essential (McNeely et al. 2001; Panetta 2007; Shah 2001). With an expected delay between the time of arrival and time of becoming invasive (Essl et al. 2011), research is needed to identify species that have already been introduced, but which have not yet become invasive, particularly garden plants (Marco et al. 2010) and pets (Rixon et al. 2005). National or regional policy responses are needed to support risk-reduction measures, including education (Marco et al. 2010). However, policy providing for regulation is essential because competition among sales outlets can increase the likelihood that species known to be invasive will be sold (Peters et al. 2006). Voluntary codes and education alone will not be effective, but in combination with regulation and enforcement, could lead to a rapid reduction in risk.

The development of new technology and adaptation of old technology is proving valuable for limiting impacts of alien invasive species. Fences are widely used to exclude invasive predatory vertebrates, both for short-term protection (Murphy et al. 2003) and for 
creating long-term "mainland islands" (Moseby et al. 2009; Richards and Short 2003; Saunders and Norton 2001). Such developments have included innovative collaboration of regional government, industry and scientists (Moseby et al. 2009), and non government organisations and scientists (e.g. http://www.australianwildlife.org/AWC-Sanctuaries/ScotiaSanctuary.aspx). Ongoing development of biological controls (Hoddle 2004), and habitat manipulation (Buckley 2008) may improve the efficiency of current control methods, and enable a broader range of invasive species to be managed. Furthermore, development and adoption of new technologies such as fertility control treatments for feral vertebrates (Jewgenow et al. 2006) or use of population genetics for planning control strategies (Hansen et al. 2007) may substantially improve our ability to ameliorate the impacts of invasive species.

\subsection{New invaders and incentives to monitor}

Besides greatly improved and expanded efforts to reduce the threat of invasive exotic species, the other critical new approach to managing invasive species under climate-change will be to distinguish between species undergoing range shifts driven by climate change, and species that have been transported beyond their natural capacity to expand. Many species are expected to shift their range with climate-change and new combinations of species may become commonplace (Lindenmayer et al. 2008b). Invasive species management of this class of new species may not be appropriate (Thomas and Ohlemüller 2009) and the decision to eradicate, accept or welcome the new invaders will be casespecific (Walther et al. 2009).

Given the expectation that many species will change their distribution and the uncertainty about the consequences (Schneider and Root 1996), systematic investment in monitoring programs is needed (Likens and Lindenmayer 2011; Lindenmayer and Likens 2010; Lovett et al. 2007; Nichols and Williams 2006). Monitoring will be most useful if it is able to detect range declines in species that are not compensated for by range expansion at a different range margin. Subsequent research may then be targeted to discover why species fail to expand, with likely explanations including barriers to dispersal (Hill et al. 2001), impacts of newly arrived species on declining species (Carroll et al. 2004; McNeely et al. 2001), or impacts of altered competitive or trophic interactions (Tylianakis et al. 2008). Efficient management responses could then be devised, and may include control of an invasive species, habitat restoration or translocations to enable appropriate compensating range expansion (subject to the caveats discussed previously about assisted migration).

Who should do this monitoring? Government-funded, national monitoring programs are already under way in many countries, often in response to obligations under the Convention on Biological Diversity (Pearman et al. 2011; Petit 2009; Reyers and McGeoch 2007). However, a number of approaches are possible for developing effective monitoring programs. Given the extensive role of international conservation organisations in some countries (Milne and Niesten 2009; Schwartzman and Zimmerman 2005), there is the potential for such organisations to lead monitoring projects in collaboration with national or regional governments (e.g. Madoffe et al. 2006). 'Citizen science' projects, funded by governments or NGOs, offer a novel but under-used monitoring approach that has enormous potential for data collection (Devictor et al. 2010; Dickinson et al. 2010). Monitoring by members of the general public could grow substantially by combining smart phone technology (Sutherland et al. 2010) with quality-controlled (such as peer-reviewed) applications and data-bases. This kind of approach is already used for monitoring many aspects of human health (e.g. Gao et al. 2009). Ecologists need to be at the fore-front of the 
push to design effective monitoring strategies using the full range of innovative tools that are increasingly available.

\section{Resource extraction and climate-change}

In addition to land clearing, there are several forms of natural resource use that are well recognised threats to biodiversity (Ludwig et al. 1993; Novacek and Cleland 2001). We highlight three examples: water extraction, livestock grazing, and forest logging. We use these examples because they are widespread practices and their impacts on biodiversity are likely to increase by interacting with, or enhancing the effects of, climate-change.

\subsection{Water extraction}

Extraction of fresh-water, including river regulation, has substantially altered natural water flows, impacting on freshwater biodiversity (Cumberlidge et al. 2009; Dudgeon et al. 2006; Kingsford 2000). Reduced and altered flows of freshwater are threatening processes in estuarine systems (Lamberth et al. 2008; Whitfield 2004), floodplains (Dunham 1994; Kingsford 2000), rivers (Taylor et al. 2008; Walker and Thoms 1993), streams (McKay and King 2006), ephemeral water bodies (Smit and Vanderhammen 1992), mound springs (Ponder et al. 1995), and ground-water ecosystems (Hancock 2002). Climate-change is likely to cause reduced precipitation and runoff in many regions of the world (IPCC 2007) and therefore will act in concert with water extraction. A number of mechanisms could be exacerbated, including increased risk of disease with lower water flow (Johnson et al. 2009), increased concentration of pollutants (Nieuwoudt 2008), altered water temperatures (Matulla et al. 2007), misalignment of the reproductive cycles of aquatic organisms with changing water flows (Gehrke et al. 1995), the creation of barriers to dispersal (Benstead et al. 1999), and more generally, the complete loss of wetland habitat (Deacon et al. 2007).

Ameliorating the combined impacts of reduced rainfall and water extraction would involve allocating more water to environmental flows (Dudgeon et al. 2006; Hancock 2002). Achieving this will require a range of policy changes, including better use of international agreements on climate, biodiversity and desertification (Duda and El-Ashry 2000). Better regulation of water extraction is needed, including policy and policing (Ghosh and Ponniah 2008). Reducing demand for water extraction is essential (Deacon et al. 2007), and may be achieved with a diverse range of approaches such as using crops that require less water (Naylor et al. 2007), desalination or recycling (Dolnicar and Schafer 2009), appropriate price signals and restrictions (Kenney et al. 2008), public education (Syme et al. 2000), and by reducing human population growth (le Blanc and Perez 2008). Delivering environmental flows will have immediate effects for some species (Kingsford and Auld 2005), although recovery of long-lived forest ecosystems may take decades or longer (Hughes and Rood 2003).

\subsection{Livestock grazing}

A reduction in rainfall in some regions (IPCC 2007), leading to increased drought, is also likely to increase the impact of grazing on some native species. Grazing livestock in uncleared rangelands and other types of remnant native vegetation can reduce biodiversity by direct consumption of palatable species (Landsberg et al. 2002), by altering the vegetation structure (Martin and Possingham 2005), by removing key food resources for 
native herbivores (Woinarski et al. 2005), and by altering soil properties (Yates et al. 2000). In dry years, when resources are generally limited, the impacts of grazing can be substantially larger because plants are more completely removed (Yarnell et al. 2007), leading to increased erosion and soil dryness (Ureta and Martorell 2009). Furthermore, grazing impacts may be highest in areas with low productivity (Lunt et al. 2007; Milchunas et al. 1988; Proulx and Mazumder 1998). In regions where rainfall declines with climatechange, productivity may be reduced, leading to increased grazing impacts. Finally, livestock impacts may be higher during drought if grazing occurs in areas that are usually set aside for conservation (Lupis et al. 2006; Morton 1990; Retzer et al. 2006). The additional stress of grazing in these refuges may appreciably increase the risk of extinction of some native species (Frank and McNaughton 1992; Retzer et al. 2006).

Solutions to these emerging issues include protecting conservation areas from "emergency" grazing. This would be achievable if conservative stocking rates were used rather than an opportunistic rate, the former being potentially more economically rewarding in addition to reducing pressure on biodiversity during drought (Campbell et al. 2000; Thurow and Taylor 1999). Commercial destocking during drought may be an option in some cases, such as the 2006 drought in Ethiopia (Abebe et al. 2008), however such international solutions would promote opportunistic stocking rates with associated environmental risks. New knowledge of ecosystem services provided by biodiversity could be an additional approach to motivate species conservation on grazing lands (Jackson et al. 2007). Delivering that motivation will require more support for ecological research combined with improved avenues for communication and outreach (Jackson et al. 2007). The Diversitas program (http://www.diversitas-international.org/) promotes such a strategy at an international level, although policies that support conservative stocking rates, ecosystem service research, and outreach are within the realms of all levels of government, such as through financial incentive schemes (Hacker et al. 2010; Rissman 2010) or by providing off-farm income options to ease financial pressures on farms (Easdale and Rosso 2010).

\subsection{Forest logging}

Our third example highlights ways that forest logging is likely to interact with the effects of climate-change to reduce biodiversity. Climate-change will cause large disturbance events to become more frequent (Allen et al. 2010; Cary 2002; Lenihan et al. 2003; Williams et al. 2001), widespread (Flannigan et al. 2005; Government of British Columbia 2009), intense (Emanuel 2005), or all of these (Franklin et al. 1991; Lenihan et al. 2003; Lewis et al. 2011). This increase in disturbance will magnify the threat to biodiversity posed by exploitative forestry operations. Of particular concern is the potential for more widespread post-disturbance (salvage) logging as the area of disturbed forest increases (Lindenmayer et al. 2008a; Spittlehouse and Stewart 2003). Post-disturbance logging reduces biodiversity through the loss of mature and dead trees, (Franklin and Agee 2003; Lindenmayer and Noss 2006), mechanical disturbance (Jonasova and Prach 2008), and the establishment of exotic plantation trees (Crisafulli et al. 2005; Sessions et al. 2004). Logging prior to disturbance will also have a negative impact by removing resources that are critical to survival of many species in the post-disturbance environment (Mazurek and Zielinski 2004; Pharo and Lindenmayer 2009). Sustainable forest management may therefore require an increasing amount of retained, unlogged elements as climate change becomes more severe. An additional interaction between logging and climate-change may increase the frequency and scale of fires in wet forest regions, to the detriment of biodiversity (Allen et al. 2010; 
Cochrane and Barber 2009; Lindenmayer et al. 1999; Thompson et al. 2007). Logging can increase the risk of ignition and provide fuel conditions that would support intense fire (Cochrane and Barber 2009; Lindenmayer et al. 2009; Thompson et al. 2007), while climate-change is likely to increase the occurrence of dangerous fire weather (Flannigan et al. 2009; Williams et al. 2001). Reducing this risk will require reduced forest exploitation (Cochrane and Barber 2009; Lindenmayer et al. 2009; Thompson et al. 2007). Careful regulation of post-disturbance logging also will be needed, including reservation of key parts of landscapes (e.g. biodiversity hotspots and riparian areas), a reduction in postdisturbance logging intensity, and consistent use of indigenous species in reafforestation programs (Lindenmayer et al. 2008a).

We acknowledge that there are ecosystems facing similar dilemmas in addition to the three we have highlighted, notably exploitation of coral reef or coastal communities that are subject to hurricane damage (Hughes et al. 2003; Michener et al. 1997; Nystrom et al. 2000), and freshwater and floodplain environments that are downstream from mines in regions that will be subject to more extreme rainfall events (Lin et al. 2006; Swales et al. 1998). We suggest that re-evaluation and modification of the way that natural resources are managed is a critical form of adaptation to climate change because many impacts that might have been manageable previously are likely to become substantially more difficult as climate-change interacts with commonplace use of natural resources.

\section{Conclusion}

In the face of global climate change, many ecological systems will adapt, transform or disappear, with the outcome eventually dictated by the success of climate change mitigation efforts. Policy makers at regional, national and international levels, land managers, and conservationists have the task of trying to maintain biodiversity and functioning ecosystems in a world of climate change. This requires a halt to the biodiversity crisis (Butchart et al. 2010; Mooney 2010) by undermining the main driving processes. We argue there are now three key and emerging drivers of the biodiversity crisis: (1) well known existing threats to biodiversity, including habitat loss and fragmentation, invasive pest species and resource exploitation, (2) direct effects of climate change, driven by increasing greenhouse gases in the atmosphere and (3) the interactions and synergisms between existing threats and climate-change. Addressing this reality requires that we do not see climate change mitigation and biodiversity preservation as an either/or trade-off, nor uncertainty as a reason for delaying action (McLachlan et al. 2007). Climate-change adaptation is intrinsically linked to reducing threats to biodiversity.

An essential global response to the worsening biodiversity crisis is to address the fundamental drivers of global change. These are increasing human population, increasing rates of resource consumption, and increasing greenhouse gas emissions (Ayres 2000; Cohen 1995; McMichael et al. 2003; Pimentel 1994; Pyšek et al. 2010). However, there is a range of critical regional responses that policy makers and land managers can take now that will mitigate some of the worst impacts of climate-change on biodiversity (Steffen et al. 2009). Increased effort to combat existing threats will substantially diminish the third driver of the biodiversity crisis. The current efforts to combat existing threats are inadequate and much greater effort is needed using existing and new approaches.

To help guide these efforts we have summarized critical policy and management actions that represent the front line of a thorough climate-change adaptation response (Table 1). Three key trends emerge. First, there are many policy and management actions that can be 


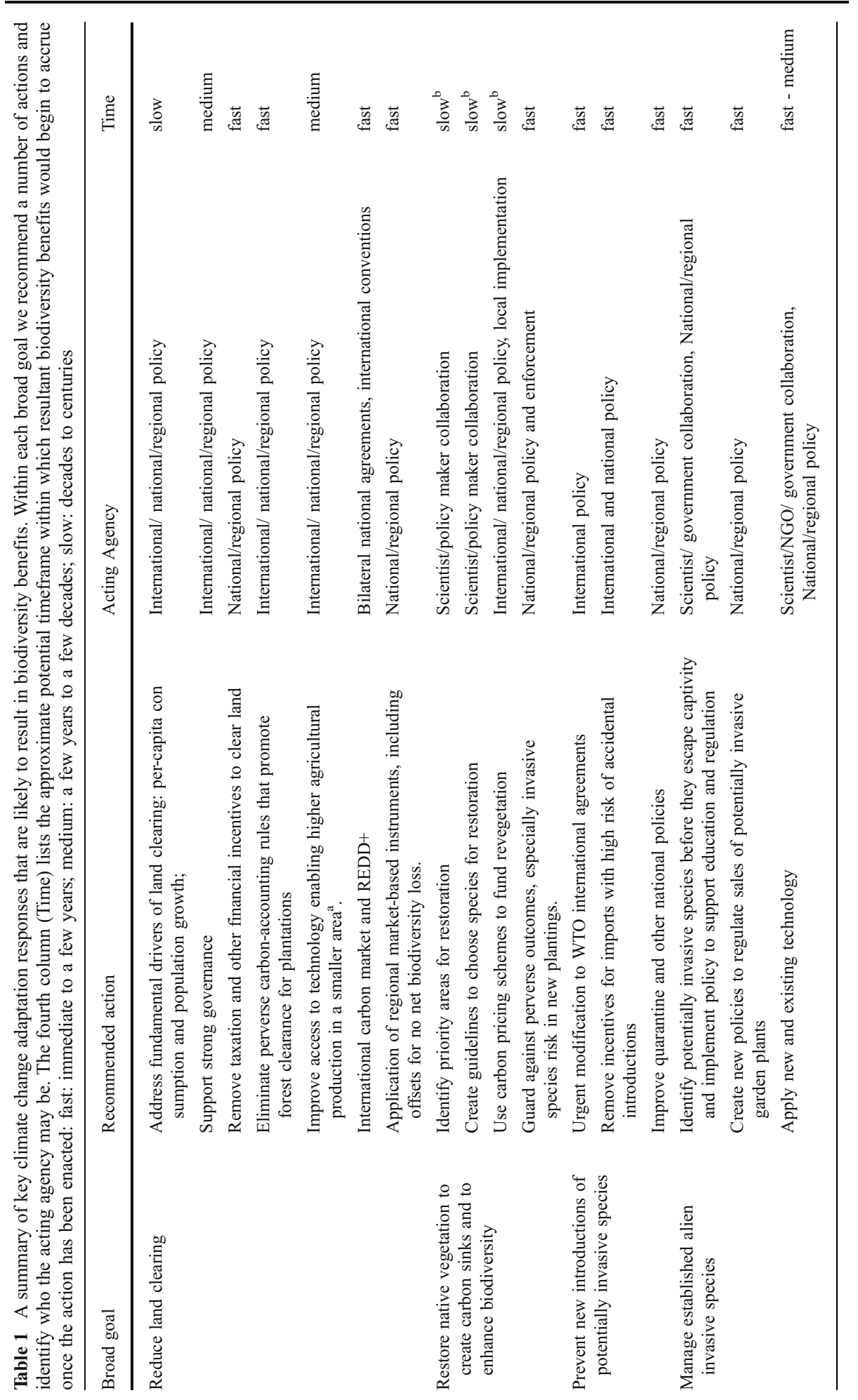







taken now and would result in a rapid reduction in the threats to biodiversity. These are principally actions that circumvent further impacts such as avoiding the introduction of new invasive species and preventing further habitat loss or degradation (Table 1). Nevertheless, actions that pay off in the medium and long-term remain essential for an effective program of adaptation to climate change. A second trend highlighted in our review is the importance of international agreements in driving or resolving threats to biodiversity (Table 1). Climate change adaptation is intrinsically linked, not just to international climate change conventions, but also international trade and conservation conventions. National effort to combat the effects of climate change must include engagement in such international negotiations, particularly those associated with international trade. The third trend emerging from our review is the importance of developing new collaborations between government, NGOs, industry, land managers and scientists to ensure better knowledge transfer, better policies and better on-ground delivery of programs. We have identified specific areas where particular groups must work together to transfer knowledge into practice via policy (Table 1).

An unfortunate by-product of the complex interaction between climate change and biodiversity loss, is the potential that key responses will be delayed. This is based on the assumption that many impacts and outcomes are uncertain and greater efficiencies will be achieved as our understanding improves. It is much easier to delay decisions under the justification of "inadequate information" than to embark on the difficult processes of informed decision making (Nichols and Williams 2006). We have shown, however, that for the vast majority of major threatening processes to biodiversity, sufficient ecological knowledge and policy options currently exist for effective adaptation efforts to be implemented or improved upon, today (Hunter et al. 2010). Policy makers and land managers can take practical action now to reduce the impacts of climate change on biodiversity (Table 1). Such actions will critically determine the trajectory that the biodiversity crisis will take over coming decades.

Acknowledgements We thank Joern Fischer and Adrian Manning for constructive discussion in developing this project. This project was supported by grants from the Australian Department of Climate-change, Land and Water Australia, the Kendall Foundation, the Australian Research Council and the Applied Environmental Decision Analysis Commonwealth Environment Research Facility.

\section{References}

Abebe D, Cullis A, Catley A, Aklilu Y, Mekonnen G, Ghebrechirstos Y (2008) Impact of a commercial destocking relief intervention in Moyale district, southern Ethiopia. Disasters 32:167-189

Allen CD, Macalady AK, Chenchouni H, Bachelet D, McDowell N, Vennetier M, Kitzberger T, Rigling A, Breshears DD, Hogg EH, Gonzalez P, Fensham R, Zhang Z, Castro J, Demidova N, Lim JH, Allard G, Running SW, Semerci A, Cobb N (2010) A global overview of drought and heat-induced tree mortality reveals emerging climate change risks for forests. For Ecol Manag 259:660-684

Anon (2007) The great divide. Nature 450:135-136

Arnalds A (2004) Carbon sequestration and the restoration of land health - an example from Iceland. Clim Change 65:333-346

Ayres E (2000) The four spikes. Futures 32:539-554

Becerra PI, Bustamante RO (2008) The effect of herbivory on seedling survival of the invasive exotic species Pinus radiata and Eucalyptus globulus in a Mediterranean ecosystem of Central Chile. For Ecol Manag 256:1573-1578

Bekessy SA, Wintle BA (2008) Using carbon investment to grow the biodiversity bank. Conserv Biol 22:510-513 
Bekessy SA, Wintle BA, Lindenmayer DB, McCarthy MA, Colyvan M, Burgman MA, Possingham HP (2010) The biodiversity bank cannot be a lending bank. Conserv Lett 3:151-158

Benstead JP, March JG, Pringle CM, Scatena FN (1999) Effects of a low-head dam and water abstraction on migratory tropical stream biota. Ecol Appl 9:656-668

Binswanger HP (1991) Brazilian policies that encourage deforestation in the Amazon. World Dev 19:821-829

Borner J, Wunder S (2008) Paying for avoided deforestation in the Brazilian Amazon: from cost assessment to scheme design. Int For Rev 10:496-511

Bortolussi G, McIvor JG, Hodgkinson JJ, Coffey SG, Holmes CR (2005) The northern Australian beef industry, a snapshot. 5. Land and pasture development practices. Aust J Exp Agric 45:1121-1129

Boykoff MT (2007) From convergence to contention: United States mass media representations of anthropogenic climate change science. Trans Inst Br Geogr 32:477-489

Brook BW, Sodhi NS, Bradshaw CJA (2008) Synergies among extinction drivers under global change. Trends Ecol Evol 23:453-460

Buckley YM (2008) The role of research for integrated management of invasive species, invaded landscapes and communities. J Appl Ecol 45:397-402

Buhrs T (2008) Climate Change Policy and New Zealand's 'National Interest': the Need for Embedding Climate Change Policy into a Sustainable Development Agenda. Polit Sci 60:61-72

Burgess ND, Bahane B, Clairs T, Danielsen F, Dalsgaard S, Funder M, Hagelberg N, Harrison P, Haule C, Kabalimu K, Kilahama F, Kilawe E, Lewis SL, Lovett JC, Lyatuu G, Marshall AR, Meshack C, Miles L, Milledge SAH, Munishi PKT, Nashanda E, Shirima D, Swetnam RD, Willcock S, Williams A, Zahabu E (2010) Getting ready for REDD plus in Tanzania: a case study of progress and challenges. Oryx 44:339-351

Burgman MA, Keith D, Hopper SD, Widyatmoko D, Drill C (2007) Threat syndromes and conservation of the Australian flora. Biol Conserv 134:73-82

Butchart SHM, Walpole M, Collen B, van Strien A, Scharlemann JPW, Almond REA, Baillie JEM, Bomhard B, Brown C, Bruno J, Carpenter KE, Carr GM, Chanson J, Chenery AM, Csirke J, Davidson NC, Dentener F, Foster M, Galli A, Galloway JN, Genovesi P, Gregory RD, Hockings M, Kapos V, Lamarque JF, Leverington F, Loh J, McGeoch MA, McRae L, Minasyan A, Morcillo MH, Oldfield TEE, Pauly D, Quader S, Revenga C, Sauer JR, Skolnik B, Spear D, Stanwell-Smith D, Stuart SN, Symes A, Tierney M, Tyrrell TD, Vie JC, Watson R (2010) Global biodiversity: indicators of recent declines. Science 328:1164-1168

Campbell BM (2009) Beyond Copenhagen: REDD plus, agriculture, adaptation strategies and poverty. Global Environ Change-Hum Pol Dimens 19:397-399

Campbell BM, Dore D, Luckert M, Mukamuri B, Gambiza J (2000) Economic comparisons of livestock production in communal grazing lands in Zimbabwe. Ecol Econ 33:413-438

Carroll AL, Taylor SW, Regniere J, Safranyik L (2004) Effects of climate change on range expansion by the mountain pine beetle in British Columbia. Mountain Pine Beetle Symposium: Challenges and Solutions 399:223-232

Carvalho SB, Brito JC, Crespo EJ, Possingham HP (2010) From climate change predictions to actions conserving vulnerable animal groups in hotspots at a regional scale. Global Change Biol 16:3257-3270

Cary GJ (2002) Importance of a changing climate for fire regimes in Australia. In: Bradstock RA, Williams JE, Gill AM (eds) Flammable Australia: the fire regimes and biodiversity of a continent. Cambridge University Press, Cambridge, pp 26-46

Cochrane MA, Barber CP (2009) Climate change, human land use and future fires in the Amazon. Global Change Biol 15:601-612

Cohen JE (1995) Population-growth and earths human carrying-capacity. Science 269:341-346

Conrad KF, Warren MS, Fox R, Parsons MS, Woiwod IP (2006) Rapid declines of common, widespread British moths provide evidence of an insect biodiversity crisis. Biol Conserv 132:279-291

Cook DC, Fraser RW (2008) Trade and invasive species risk mitigation: reconciling WTO compliance with maximising the gains from trade. Food Pol 33:176-184

Cook DC, Liu SG, Murphy B, Lonsdale WM (2010) Adaptive approaches to biosecurity governance. Risk Anal 30:1303-1314

Copp GH, Templeton M, Gozlan RE (2007) Propagule pressure and the invasion risks of non-native freshwater fishes: a case study in England. J Fish Biol 71:148-159

Corbera E, Estrada M, Brown K (2010) Reducing greenhouse gas emissions from deforestation and forest degradation in developing countries: revisiting the assumptions. Clim Change 100:355-388

Costa GS, Franco AA, Damasceno RN, Faria SM (2004) Nutrient input through litter in a degraded area revegetated with legume trees. Rev Bras Cienc Solo 28:919-927

Crisafulli CM, Swanson FJ, Dale VH (2005) Overview of ecological responses to the eruption of Mount St. Helens: 1980-2005. In: Dale VH, Swanson FJ, Crisafulli CM (eds) Ecological responses to the eruption of Mount St. Helens. Springer, New York 
Cumberlidge N, Ng PKL, Yeo DCJ, Magalhaes C, Campos MR, Alvarez F, Naruse T, Daniels SR, Esser LJ, Attipoe FYK, Clotilde-Ba FL, Darwall W, McIvor A, Baillie JEM, Collen B, Ram M (2009) Freshwater crabs and the biodiversity crisis: importance, threats, status, and conservation challenges. Biol Conserv 142:1665-1673

D’Antonio CM, Vitousek PM (1992) Biological invasions by exotic grasses, the grass fire cycle, and global change. Annu Rev Ecol Syst 23:63-87

Deacon JE, Williams AE, Williams CD, Williams JE (2007) Fueling population growth in Las Vegas: how large-scale groundwater withdrawal could burn regional biodiversity. Bioscience 57:688-698

Deo RC, Syktus JI, McAlpine CA, Lawrence PJ, McGowan HA and Phinn SR (2009) Impact of historical land cover change on daily indices of climate extremes including droughts in eastern Australia. Geophys Res Lett 36

Desantis LRG, Bhotika S, Williams K, Putz FE (2007) Sea-level rise and drought interactions accelerate forest decline on the Gulf Coast of Florida, USA. Global Change Biol 13:2349-2360

Devictor V, Whittaker RJ, Beltrame C (2010) Beyond scarcity: citizen science programmes as useful tools for conservation biogeography. Divers Distrib 16:354-362

Dickinson JL, Zuckerberg B and Bonter DN (2010) Citizen science as an ecological research tool: challenges and benefits. Annual review of ecology, evolution, and systematics, Vol 41. Annual Reviews, Palo Alto, pp 149-172

Dolnicar S, Schafer AI (2009) Desalinated versus recycled water: public perceptions and profiles of the accepters. J Environ Manag 90:888-900

Duda AM, El-Ashry MT (2000) Addressing the global water and environment crises through integrated approaches to the management of land, water and ecological resources. Water Int 25:115-126

Dudgeon D, Arthington AH, Gessner MO, Kawabata ZI, Knowler DJ, Leveque C, Naiman RJ, PrieurRichard AH, Soto D, Stiassny MLJ, Sullivan CA (2006) Freshwater biodiversity: importance, threats, status and conservation challenges. Biol Rev 81:163-182

Dukes JS, Mooney HA (1999) Does global change increase the success of biological invaders? Trends Ecol Evol 14:135-139

Duncan RP, Blackburn TM (2004) Extinction and endemism in the New Zealand avifauna. Global Ecol Biogeogr 13:509-517

Dunham KM (1994) The effect of drought on the large mammal populations of Zambezi riverine woodlands. J Zool 234:489-526

Dwyer JM, Fensham RJ, Butler DW, Buckley YM (2009) Carbon for conservation: Assessing the potential for win-win investment in an extensive Australian regrowth ecosystem. Agric Ecosyst Environ 134:1-7

Easdale MH, Rosso H (2010) Dealing with drought: social implications of different smallholder survival strategies in semi-arid rangelands of Northern Patagonia, Argentina. Rangeland J 32:247-255

Ebeling J, Yasue M (2008) Generating carbon finance through avoided deforestation and its potential to create climatic, conservation and human development benefits. Phil Trans Roy Soc B Biol Sci 363:1917-1924

Ehrlich PR, Holden JP (1974) Impact of population growth. Science 171:1212-1217

Emanuel K (2005) Increasing destructiveness of tropical cyclones over the past 30 years. Nature 436:686-688

Essl F, Dullinger S, Rabitsch W, Hulme PE, Hülber K, Jarošík V, Kleinbauer I, Krausmann F, Kühn I, Nentwig W, Vilà M, Genovesi P, Gherardi F, Desprez-Loustau M-L, Roques A, Pyšek P (2011) Socioeconomic legacy yields an invasion debt. Proc Natl Acad Sci 108:203-207

Ewers RM, Scharlemann JPW, Balmford A, Green RE (2009) Do increases in agricultural yield spare land for nature? Global Change Biol 15:1716-1726

FAO (2005) Global Forest Resources Assessment 2005. Food and Agriculture Organization of the United Nations, Rome

Fazey I, Fischer J (2009) Assisted colonization is a techno-fix. Trends Ecol Evol 24:475-475

Felton A, Fischer J, Lindenmayer DB, Montague-Drake R, Lowe AR, Saunders D, Felton AM, Steffen W, Munro NT, Youngentob K, Gillen J, Gibbons P, Bruzgul JE, Fazey I, Bond SJ, Elliott CP, Macdonald BCT, Porfirio LL, Westgate M, Worthy M (2009) Climate change, conservation and management: an assessment of the peer-reviewed scientific journal literature. Biodivers Conserv 18:2243-2253

Fine PVA (2002) The invasibility of tropical forests by exotic plants. J Trop Ecol 18:687-705

Firth RSC, Woinarski JCZ, Brennan KG, Hempel C (2006) Environmental relationships of the brush-tailed rabbit-rat, Conilurus penicillatus, and other small mammals on the Tiwi Islands, northern Australia. J Biogeogr 33:1820-1837

Fischer J, Stott J, Law BS (2010) The disproportionate value of scattered trees. Biol Conserv 143:1564-1567

Flannigan MD, Logan KA, Amiro BD, Skinner WR, Stocks BJ (2005) Future area burned in Canada. Clim Change 72:1-16

Flannigan M, Stocks B, Turetsky M, Wotton M (2009) Impacts of climate change on fire activity and fire management in the circumboreal forest. Global Change Biol 15:549-560 
Frank DA, McNaughton SJ (1992) The ecology of plants, large mammalian herbivores, and drought in Yellowstone National Park. Ecology 73:2043-2058

Franklin JF, Agee JK (2003) Forging a science-based national forest fire policy. Issues Sci Technol 20:59-66

Franklin JF, Swanson FJ, Harmon ME, Perry DA, Spies TA, Dale VH, McKee A, Ferrell WK, Means JE, Gregory SV, Lattin JD, Schowalter TD, Larsen D (1991) Effects of global climate change on forests in northwestern North America. NW Environ J 7:233-254

Gao CM, Kong FY, Tan JD, Ieee (2009) HealthAware: tackling obesity with health aware smart phone systems. Ieee, New York

Gatewood S (2003) The Wildlands Project: The Yellowstone to Yukon conservation initiative and Sky Islands Wildlands Network. Protected Areas and the Regional Planning Imperative in North America 7:235-245

Gaveau DLA, Linkie M, Suyadi LP, Leader-Williams N (2009) Three decades of deforestation in southwest Sumatra: effects of coffee prices, law enforcement and rural poverty. Biol Conserv 142:597-605

Gehrke PC, Brown P, Schiller CB, Moffatt DB, Bruce AM (1995) River regulation and fish communities in the Murray-Darling river system, Australia. Regulated Rivers-Research \& Management 11:363-375

Ghosh SK, Ponniah AG (2008) Freshwater fish habitat science and management in India. Aquat Ecosys Health Manag 11:272-288

Gibbons P, Lindenmayer DB (2007) Offsets for land clearing: no net loss or the tail wagging the dog? Ecol Manag Restor 8:26-31

Goulson D (2003) Effects of introduced bees on native ecosystems. Annu Rev Ecol Evol Syst 34:1-26

Government of British Columbia (2009) Mountain Pine Beetles in British Columbia. www.for.gov.bc.ca/hfp/ mountain pine beetle/ Last accessed 18.2.2009

Green RE, Cornell SJ, Scharlemann JPW, Balmford A (2005) Farming and the fate of wild nature. Science 307:550-555

Groves RH, Boden R, Lonsdale WM (2005) Jumping the Garden Fence. Invasive garden plants in Australia and their environmental and agricultural impacts. CSIRO report prepared for WWF-Australia. WWF-Australia, Sydney

Gullison RE, Frumhoff PC, Canadell JG, Field CB, Nepstad DC, Hayhoe K, Avissar R, Curran LM, Friedlingstein P, Jones CD, Nobre C (2007) Tropical forests and climate policy. Science 316:985-986

Hacker RB, Jessop PJ, Smith WJ, Melville GJ (2010) A ground cover-based incentive approach to enhancing resilience in rangelands viewed as complex adaptive systems. Rangeland J 32:283-291

Hancock PJ (2002) Human impacts on the stream-groundwater exchange zone. Environ Manag 29:763-781

Hansen H, Hess SC, Cole D, Banko PC (2007) Using population genetic tools to develop a control strategy for feral cats (Felis catus) in Hawai'i. Wildl Res 34:587-596

Harwood CE, Alloysius D, Pomroy P, Robson KW, Haines MW (1997) Early growth and survival of Eucalyptus pellita provenances in a range of tropical environments, compared with E-grandis, Europhylla and Acacia mangium. New For 14:203-219

Haskett J, Schlamadinger B, Brown S (2010) Land-based carbon storage and the European union emissions trading scheme: the science underlying the policy. Mitig Adapt Strateg Glob Chang 15:127-136

Heath LS, Joyce LA (1997) Carbon sequestration in forests as a national policy issue. Communicating the Role of Silviculture in Managing the National Forests. Proceedings of the National Silviculture Workshop 238:29-36

Heller NE, Zavaleta ES (2009) Biodiversity management in the face of climate change: a review of 22 years of recommendations. Biol Conserv 142:14-32

Hellmann JJ, Byers JE, Bierwagen BG, Dukes JS (2008) Five potential consequences of climate change for invasive species. Conserv Biol 22:534-543

Hill JK, Collingham YC, Thomas CD, Blakeley DS, Fox R, Moss D, Huntley B (2001) Impacts of landscape structure on butterfly range expansion. Ecol Lett 4:313-321

Hingston AB, Marsden-Smedley J, Driscoll DA, Corbett S, Fenton J, Anderson R, Plowman C, Mowling F, Jenkin M, Matsui K, Bonham KJ, Ilowski M, McQuillan PB, Yaxley B, Reid T, Storey D, Poole L, Mallick SA, Fitzgerald N, Kirkpatrick JB, Febey J, Harwood AG, Michaels KF, Russell MJ, Black PG, Emmerson L, Visoiu M, Morgan J, Breen S, Gates S, Bantich MN, Desmarchelier JM (2002) Extent of invasion of Tasmanian native vegetation by the exotic bumblebee Bombus terrestris (Apoidea: Apidae). Aust Ecol 27:162-172

Hobbs RJ, Higgs E, Harris JA (2009) Novel ecosystems: implications for conservation and restoration. Trends Ecol Evol 24:599-605

Hoddle MS (2004) Restoring balance: using exotic species to control invasive exotic species. Conserv Biol 18:38-49

Hodgson JA, Thomas CD, Wintle BA, Moilanen A (2009) Climate change, connectivity and conservation decision making: back to basics. J Appl Ecol 46:964-969

Hoegh-Guldberg O, Mumby PJ, Hooten AJ, Steneck RS, Greenfield P, Gomez E, Harvell CD, Sale PF, Edwards AJ, Caldeira K, Knowlton N, Eakin CM, Iglesias-Prieto R, Muthiga N, Bradbury RH, Dubi A, Hatziolos ME (2007) Coral reefs under rapid climate change and ocean acidification. Science 318:1737-1742 
Hoegh-Guldberg O, Hughes L, McIntyre S, Lindenmayer DB, Parmesan C, Possingham HP, Thomas CD (2008) Assisted colonization and rapid climate change. Science 321:345-346

Houghton RA (2003) Revised estimates of the annual net flux of carbon to the atmosphere from changes in land use and land management 1850-2000. Tellus Series B-Chemical and Physical Meteorology 55:378-390

Houghton RA (2007) Balancing the global carbon budget. Annu Rev Earth Planet Sci 35:313-347

Hughes FMR, Rood SB (2003) Allocation of river flows for restoration of floodplain forest ecosystems: a review of approaches and their applicability in Europe. Environ Manag 32:12-33

Hughes L, Cawsey EM, Westoby M (1996) Climatic range sizes of Eucalyptus species in relation to future climate change. Global Ecol Biogeogr Lett 5:23-29

Hughes TP, Baird AH, Bellwood DR, Card M, Connolly SR, Folke C, Grosberg R, Hoegh-Guldberg O, Jackson JBC, Kleypas J, Lough JM, Marshall P, Nystrom M, Palumbi SR, Pandolfi JM, Rosen B, Roughgarden J (2003) Climate change, human impacts, and the resilience of coral reefs. Science 301:929-933

Hulme PE (2009) Trade, transport and trouble: managing invasive species pathways in an era of globalization. J Appl Ecol 46:10-18

Hulme PE, Bacher S, Kenis M, Klotz S, Kuhn I, Minchin D, Nentwig W, Olenin S, Panov V, Pergl J, Pysek P, Roques A, Sol D, Solarz W, Vila M (2008) Grasping at the routes of biological invasions: a framework for integrating pathways into policy. J Appl Ecol 45:403-414

Hulme PE, Nentwig W, Pysek P, Vila M (2009) Common market, shared problems: time for a coordinated response to biological invasions in Europe? In: Pysek P, Pergl J (eds) Biological invasions: towards a synthesis, proceedings. Institut Ecology Tu Berlin, Berlin, pp 3-19

Hunter M, Dinerstein E, Hoekstra J, Lindenmayer D (2010) A call to action for conserving biological diversity in the face of climate change. Conserv Biol 24:1169-1171

Huntley B (1999) The dynamic response of plants to environmental change and the resulting risks of extinction. In: Mace GM, Balmford A, Ginsberg JR (eds) Conservation in a changing world. Cambridge University Press, Cambridge, pp 69-85

IPCC (2007) Climate change 2007. Synthesis report. Intergovernmental Panel on Climate Change, Geneva

Jackson ST, Hobbs RJ (2009) Ecological restoration in the light of ecological history. Science 325:567-569

Jackson LE, Pascual U, Hodgkin T (2007) Utilizing and conserving agrobiodiversity in agricultural landscapes. Agric Ecosyst Environ 121:196-210

Jefferson L, Havens K, Ault J (2004) Implementing invasive screening procedures: the Chicago Botanic Garden model. Weed Tech 18:1434-1440

Jewgenow K, Dehnhard M, Hildebrandt TB, Goritz F (2006) Contraception for population control in exotic carnivores. Theriogenology 66:1525-1529

Johnson AC, Acreman MC, Dunbar MJ, Feist SW, Giacomello AM, Gozlan RE, Hinsley SA, Ibbotson AT, Jarvie HP, Jones JI, Longshaw M, Maberly SC, Marsh TJ, Neal C, Newman JR, Nunn MA, Pickup RW, Reynard NS, Sullivan CA, Sumpter JP, Williams RJ (2009) The British river of the future: how climate change and human activity might affect two contrasting river ecosystems in England. Sci Total Environ 407:4787-4798

Jonasova M, Prach K (2008) The influence of bark beetles outbreak vs. salvage logging on ground layer vegetation in Central European mountain spruce forests. Biol Conserv 141:1525-1535

Jump AS, Penuelas J (2005) Running to stand still: adaptation and the response of plants to rapid climate change. Ecol Lett 8:1010-1020

Kahn S, Pelgrim W (2010) The role of the World Trade Organization and the 'three sisters' (the World Organisation for Animal Health, the International Plant Protection Convention and the Codex Alimentarius Commission) in the control of invasive alien species and the preservation of biodiversity. Rev Sci Tech Off Int Epizoot 29:411-417

Kaufmann D, Kraay A, Zoido-Lobatón P (1999) Governance Matters. Policy Research Working Paper 2196. The World Bank, Washington DC

Keith DA, Akcakaya HR, Thuiller W, Midgley GF, Pearson RG, Phillips SJ, Regan HM, Araujo MB, Rebelo TG (2008) Predicting extinction risks under climate change: coupling stochastic population models with dynamic bioclimatic habitat models. Biol Lett 4:560-563

Keller RP, Lodge DM, Finnoff DC (2007) Risk assessment for invasive species produces net bioeconomic benefits. Proc Natl Acad Sci USA 104:203-207

Kenney DS, Goemans C, Klein R, Lowrey J, Reidy K (2008) Residential water demand management: lessons from Aurora, Colorado. J Am Water Resour Assoc 44:192-207

Kindermann G, Obersteiner M, Sohngen B, Sathaye J, Andrasko K, Rametsteiner E, Schlamadinger B, Wunder S, Beach R (2008) Global cost estimates of reducing carbon emissions through avoided deforestation. Proc Natl Acad Sci USA 105:10302-10307

Kingsford RT (2000) Ecological impacts of dams, water diversions and river management on floodplain wetlands in Australia. Aust Ecol 25:109-127 
Kingsford RT, Auld KM (2005) Waterbird breeding and environmental flow management in the Macquarie Marshes, Arid Australia. River Res Appl 21:187-200

Kishor N, Belle A (2004) Does improved governance contribute to sustainable forest management? J Sustain For 19:55-79

Kotiluoto R, Ruokolainen K, Kettunen M (2009) Invasive Acacia auriculiformis Benth. in different habitats in Unguja, Zanzibar. Afr J Ecol 47:77-86

Kula E (2010) Afforestation with carbon sequestration and land use policy in Northern Ireland. Land Use Pol 27:749-752

Lamberth SJ, van Niekerk L, Hutchings K (2008) Comparison of, and the effects of altered freshwater inflow on, fish assemblages of two contrasting South African estuaries: the cool-temperate Olifants and the warm-temperate Breede. Afr J Mar Sci 30:311-336

Lambin EF, Turner BL, Geist HJ, Agbola SB, Angelsen A, Bruce JW, Coomes OT, Dirzo R, Fischer G, Folke C, George PS, Homewood K, Imbernon J, Leemans R, Li X, Moran EF, Mortimore M, Ramakrishnan PS, Richards JF, Skånes H, Steffen W, Stone GD, Svedin U, Veldkamp TA, Vogel C, Xu J (2001) The causes of land-use and land-cover change: moving beyond the myths. Global Environ Change 11:261-269

Lande R (1998) Anthropogenic, ecological and genetic factors in extinction and conservation. Res Popul Ecol 40:259-269

Landsberg J, James CD, Maconochie J, Nicholls AO, Stol J, Tynan R (2002) Scale-related effects of grazing on native plant communities in an arid rangeland region of South Australia. J Appl Ecol 39:427-444

Laurance WF (2007) Have we overstated the tropical biodiversity crisis? Trends Ecol Evol 22:65-70

Laurance WF (2008) Global warming and amphibian extinctions in eastern Australia. Aust Ecol 33:1-9

Lawler JJ (2009) Climate change adaptation strategies for resource management and conservation planning. Ann N Y Acad Sci 1162:79-98

le Blanc D, Perez R (2008) The relationship between rainfall and human density and its implications for future water stress in Sub-Saharan Africa. Ecol Econ 66:319-336

Lenihan JM, Drapek R, Bachelet D, Neilson RP (2003) Climate change effects on vegetation distribution, carbon, and fire in California. Ecol Appl 13:1667-1681

Lewis OT (2006) Climate change, species-area curves and the extinction crisis. Phil Trans Roy Soc B Biol Sci 361:163-171

Lewis SL, Brando PM, Phillips OL, van der Heijden GMF, Nepstad D (2011) The 2010 Amazon Drought. Science 331:554-554

Likens GE, Lindenmayer DB (2011) A strategic plan for an Australian long-term environmental monitoring network. Aust Ecol 36:1-8

Lin C, Wu Y, Lu W, Chen A, Liu Y (2006) Impacts of acid mine drainage on a stream in subtropical China during a major flood event. Chin J Geochem 25(suppl):39

Lindemann-Matthies P, Bose E (2008) How many species are there? Public understanding and awareness of biodiversity in Switzerland. Hum Ecol 36:731-742

Lindenmayer DB (2009) Forest wildlife management and conservation. Ann N Y Acad Sci 1162:284-310

Lindenmayer DB, Likens GE (2010) Monitoring for ecological knowledge. CSIRO Publishing and Oxford University Press, Melbourne

Lindenmayer DB, Noss RF (2006) Salvage logging, ecosystem processes, and biodiversity conservation. Conserv Biol 20:949-958

Lindenmayer DB, Cunningham RB, McCarthy MA (1999) The conservation of arboreal marsupials in the montane ash forests of the central highlands of Victoria, south-eastern Australia. VIII. Landscape analysis of the occurrence of arboreal marsupials. Biol Conserv 89:83-92

Lindenmayer DB, Burton P, Franklin JF (2008a) Salvage logging and its ecological consequences. Island, Washington, D.C

Lindenmayer DB, Fischer J, Felton A, Crane M, Michael D, MacGregor C, Montague-Drake R, Manning A, Hobbs RJ (2008b) Novel ecosystems resulting from landscape transformation create dilemmas for modern conservation practice. Conserv Lett 1:129-135

Lindenmayer BD, Hunter ML, Burton PJ, Gibbons P (2009) Effects of logging on fire regimes in moist forests. Conserv Lett 2:271-277

Lockwood JL (1999) Using taxonomy to predict success among introduced avifauna: relative importance of transport and establishment. Conserv Biol 13:560-567

Los SO, Weedon GP, North PRJ, Kaduk JD, Taylor CM and Cox PM (2006) An observation-based estimate of the strength of rainfall-vegetation interactions in the Sahel. Geophys Res Lett 33

Lovett GM, Burns DA, Driscoll CT, Jenkins JC, Mitchell MJ, Rustad L, Shanley JB, Likens GE, Haeuber R (2007) Who needs environmental monitoring? Front Ecol Environ 5:253-260

Ludwig D, Hilborn R and Walters C (1993) Uncertainty, resource exploitation, and conservation - lessons from history. Science 260:17-18 
Lunt ID, Jansen A, Binns DL, Kenny SA (2007) Long-term effects of exclusion of grazing stock on degraded herbaceous plant communities in a riparian Eucalyptus camaldulensis forest in south-eastern Australia. Aust Ecol 32:937-949

Lupis SG, Messmer TA, Black T (2006) Gunnison sage-grouse use of Conservation Reserve Program fields in Utah and response to emergency grazing: a preliminary evaluation. Wildl Soc Bull 34:957-962

Mack RN (1996) Predicting the identity and fate of plant invaders: emergent and emerging approaches. Biol Conserv 78:107-121

Mack RN, Simberloff D, Lonsdale WM, Evans H, Clout M, Bazzaz FA (2000) Biotic invasions: causes, epidemiology, global consequences, and control. Ecol Appl 10:689-710

Madoffe S, Hertel GD, Rodgers P, O'Connell B, Killenga R (2006) Monitoring the health of selected eastern arc forests in Tanzania. Afr J Ecol 44:171-177

Manning AD, Fischer J, Lindenmayer DB (2006) Scattered trees are keystone structures - implications for conservation. Biol Conserv 132:311-321

Marco A, Lavergne S, Dutoit T, Bertaudiere-Montes V (2010) From the backyard to the backcountry: how ecological and biological traits explain the escape of garden plants into Mediterranean old fields. Biol Invasions 12:761-779

Marini MA, Barbet-Massin M, Lopes LE, Jiguet F (2009) Predicted climate-driven bird distribution changes and forecasted conservation conflicts in a neotropical savanna. Conserv Biol 23:1558-1567

Martin TG, Possingham HP (2005) Predicting the impact of livestock grazing on birds using foraging height data. J Appl Ecol 42:400-408

Matulla C, Schmutz S, Melcher A, Gerersdorfer T, Haas P (2007) Assessing the impact of a downscaled climate change simulation on the fish fauna in an Inner-Alpine River. Int J Biometeorol 52:127-137

Mazurek MJ, Zielinski WJ (2004) Individual legacy trees influence vertebrate wildlife diversity in commercial forests. For Ecol Manag 193:321-334

McAlpine CA, Syktus J, Deo RC, Lawrence PJ, McGowan HA, Watterson IG and Phinn SR (2007) Modeling the impact of historical land cover change on Australia's regional climate. Geophys Res Lett 34

McAlpine CA, Syktus J, Ryan JG, Deo RC, McKeon GM, McGowan HA, Phinn SR (2009) A continent under stress: interactions, feedbacks and risks associated with impact of modified land cover on Australia's climate. Global Change Biol 15:2206-2223

McCallum ML (2007) Amphibian decline or extinction? Current declines dwarf background extinction rate. J Herpetol 41:483-491

McKay SF, King AJ (2006) Potential ecological effects of water extraction in small, unregulated streams. River Res Appl 22:1023-1037

McLachlan JS, Hellmann JJ, Schwartz MW (2007) A framework for debate of assisted migration in an era of climate change. Conserv Biol 21:297-302

McMichael AJ, Butler CD, Folke C (2003) New visions for addressing sustainability. Science 302:1919-1920

McNeely JA, Mooney HA, Neville L, Schei PJ, Waage JK (2001) A global strategy on invasive alien species. IUCN, Gland, Switzerland, and Cambridge, UK

Michener WK, Blood ER, Bildstein KL, Brinson MM, Gardner LR (1997) Climate change, hurricanes and tropical storms, and rising sea level in coastal wetlands. Ecol Appl 7:770-801

Milchunas DG, Sala OE, Lauenroth WK (1988) A generalized-model of the effects of grazing by large herbivores on grassland community structure. Am Nat 132:87-106

Millennium Ecosystem Assessment (2005) Ecosystems and human well-being: biodiversity synthesis. World Resources Institute, Washington, DC

Milne S, Niesten E (2009) Direct payments for biodiversity conservation in developing countries: practical insights for design and implementation. Oryx 43:530-541

Mooney HA (2010) The ecosystem-service chain and the biological diversity crisis. Phil Trans Roy Soc B Biol Sci 365:31-39

Mooney HA, Hobbs RJ (2000) Invasive species in a changing world. Island, Washington DC

Morton SR (1990) The impact of European settlement on the vertebrate animals of arid Australia: a conceptual model. Proc Ecol Soc Aust 16:201-213

Moseby KE, Hill BM, Read JL (2009) Arid Recovery - A comparison of reptile and small mammal populations inside and outside a large rabbit, cat and fox-proof exclosure in arid South Australia. Aust Ecol 34:156-169

Mueller JM, Hellmann JJ (2008) An assessment of invasion risk from assisted migration. Conserv Biol 22:562-567

Murphy RK, Greenwood RJ, Ivan JS, Smith KA (2003) Predator exclusion methods for managing endangered shorebirds: are two barriers better than one? Waterbirds 26:156-159

Naylor RL, Battisti DS, Vimont DJ, Falcon WP, Burke MB (2007) Assessing risks of climate variability and climate change for Indonesian rice agriculture. Proc Natl Acad Sci USA 104:7752-7757 
Nichols JD, Williams BK (2006) Monitoring for conservation. Trends Ecol Evol 21:668-673

Nichols PGH, Loi A, Nutt BJ, Evans PM, Craig AD, Pengelly BC, Dear BS, Lloyd DL, Revell CK, Nair RM, Ewing MA, Howieson JG, Auricht GA, Howie JH, Sandral GA, Carr SJ, de Koning CT, Hackney BF, Crocker GJ, Snowball R, Hughes EJ, Hall EJ, Foster KJ, Skinner PW, Barbetti MJ, You MP (2006) New annual and short-lived perennial pasture legumes for Australian agriculture - 15 years of revolution. Elsevier Science Bv, Perth, pp 10-23

Nieuwoudt WL (2008) Environmental offsets and other market approaches with specific reference to the Olifants River (East) and Berg River. Agrekon 47:433-450

Nogue S, Rull V, Vegas-Vilarrubia T (2009) Modeling biodiversity loss by global warming on Pantepui, northern South America: projected upward migration and potential habitat loss. Clim Change 94:77-85

Novacek MJ (2008) Engaging the public in biodiversity issues. Proc Natl Acad Sci USA 105:11571-11578

Novacek MJ, Cleland EE (2001) The current biodiversity extinction event: scenarios for mitigation and recovery. Proc Natl Acad Sci USA 98:5466-5470

Nystrom M, Folke C, Moberg F (2000) Coral reef disturbance and resilience in a human-dominated environment. Trends Ecol Evol 15:413-417

Opdam P, Wascher D (2004) Climate change meets habitat fragmentation: linking landscape and biogeographical scale levels in research and conservation. Biol Conserv 117:285-297

Panetta FD (2007) Evaluation of weed eradication programs: containment and extirpation. Divers Distrib 13:33-41

Parmesan C (2006) Ecological and evolutionary responses to recent climate change. Annu Rev Ecol Evol Syst 37:637-669

Pearman PB, Guisan A, Zimmermann NE (2011) Impacts of climate change on Swiss biodiversity: an indicator taxa approach. Biol Conserv 144:866-875

Perrings C, Burgiel S, Lonsdale M, Mooney H, Williamson M (2010) International cooperation in the solution to trade-related invasive species risks. Year in Ecology and Conservation Biology 2010. Blackwell, Oxford, pp 198-212

Peters WL, Meyer MH, Anderson NO (2006) Minnesota horticultural industry survey on invasive plants. Euphytica 148:75-86

Petit S (2009) The dimensions of land use change in rural landscapes: lessons learnt from the GB Countryside Surveys. J Environ Manag 90:2851-2856

Pharo H (2006) Acceptable risk in animal biosecurity import risk analysis: the New Zealand experience. Vet Ital 42:337-349

Pharo EJ, Lindenmayer DB (2009) Biological legacies soften pine plantation effects for bryophytes. Biodivers Conserv 18:1751-1764

Pimentel D (1994) Global population, food and the environment. Trends Ecol Evol 9:239

Pimentel D, Zuniga R, Morrison D (2005) Update on the environmental and economic costs associated with alien-invasive species in the United States. Ecol Econ 52:273-288

Pimm SL, Raven P (2000) Extinction by numbers. Nature 403:843-845

Pimm S, Raven P, Peterson A, Sekercioglu CH, Ehrlich PR (2006) Human impacts on the rates of recent, present, and future bird extinctions. Proc Natl Acad Sci USA 103:10941-10946

Pineiro G, Jobbaggy EG, Baker J, Murray BC, Jackson RB (2009) Set-asides can be better climate investment than corn ethanol. Ecol Appl 19:277-282

Pitman NCA, Jorgensen PM, Williams RSR, Leon-Yanez S, Valencia R (2002) Extinction-rate estimates for a modern neotropical flora. Conserv Biol 16:1427-1431

Plantinga AJ, Wu JJ (2003) Co-benefits from carbon sequestration in forests: evaluating reductions in agricultural externalities from an afforestation policy in Wisconsin. Land Econ 79:74-85

Ponder WF, Eggler P, Colgan DJ (1995) Genetic differentiation of aquatic snails (Gastropoda:Hydrobiidae) from artesian springs in arid Australia. Biol J Linn Soc 56:553-596

Primack RB, Miao SL (1992) Dispersal can limit local plant distribution. Conserv Biol 6:513-519

Proulx M, Mazumder A (1998) Reversal of grazing impact on plant species richness in nutrient-poor vs. nutrient-rich ecosystems. Ecology 79:2581-2592

Pyke CR, Thomas R, Porter RD, Hellmann JJ, Dukes JS, Lodge DM, Chavarria G (2008) Current practices and future opportunities for policy on climate change and invasive species. Conserv Biol 22:585-592

Pyšek P, Jarošík V, Hulme PE, Kühn I, Wild J, Arianoutsou M, Bacher S, Chiron F, Didžiulis V, Essl F, Genovesi P, Gherardi F, Hejda M, Kark S, Lambdon PW, Desprez-Loustau M-L, Nentwig W, Pergl J, Poboljšaj K, Rabitsch W, Roques A, Roy DB, Shirley S, Solarz W, Vilà M, Winter M (2010) Disentangling the role of environmental and human pressures on biological invasions across Europe. Proc Natl Acad Sci 107:12157-12162

Rachowicz LJ, Hero JM, Alford RA, Taylor JW, Morgan JAT, Vredenburg VT, Collins JP, Briggs CJ (2005) The novel and endemic pathogen hypotheses: competing explanations for the origin of emerging infectious diseases of wildlife. Conserv Biol 19:1441-1448 
Rahel FJ, Olden JD (2008) Assessing the effects of climate change on aquatic invasive species. Conserv Biol 22:521-533

Ramankutty N, Gibbs HK, Achard F, Defriess R, Foley JA, Houghton RA (2007) Challenges to estimating carbon emissions from tropical deforestation. Global Change Biol 13:51-66

Ren H, Lu HF, Shen WJ, Huang C, Guo QF, Li ZA, Jian SG (2009) Sonneratia apetala Buch. Ham in the mangrove ecosystems of China: an invasive species or restoration species? Ecol Eng 35:1243-1248

Retzer V, Nadrowski K, Miehe G (2006) Variation of precipitation and its effect on phytomass production and consumption by livestock and large wild herbivores along an altitudinal gradient during a drought, South Gobi, Mongolia. J Arid Environ 66:135-150

Reyers B, McGeoch MA (2007) A biodiversity monitoring framework for South Africa: progress and directions. S Afr J Sci 103:295-300

Ricciardi A (2007) Are modern biological invasions an unprecedented form of global change? Conserv Biol 21:329-336

Ricciardi A, Simberloff D (2009a) Assisted colonization is not a viable conservation strategy. Trends Ecol Evol 24:248-253

Ricciardi A, Simberloff D (2009b) Assisted colonization: good intentions and dubious risk assessment. Trends Ecol Evol 24:476-477

Richards JD, Short J (2003) Reintroduction and establishment of the western barred bandicoot Perameles bougainville (Marsupialia: Peramelidae) at Shark Bay, Western Australia. Biol Conserv 109:181-195

Richardson DM (1998) Forestry trees as invasive aliens. Conserv Biol 12:18-26

Richardson DM, Hellmann JJ, McLachlan JS, Sax DF, Schwartz MW, Gonzalez P, Brennan EJ, Camacho A, Root TL, Sala OE, Schneider SH, Ashe DM, Clark JR, Early R, Etterson JR, Fielder ED, Gill JL, Minteer BA, Polasky S, Safford HD, Thompson AR, Vellend M (2009) Multidimensional evaluation of managed relocation. Proc Natl Acad Sci USA 106:9721-9724

Ring I, Drechsler M, van Teeffelen AJA, Irawan S, Venter O (2010) Biodiversity conservation and climate mitigation: what role can economic instruments play? Curr Opin Environ Sustain 2:50-58

Rissman AR (2010) Designing perpetual conservation agreements for land management. Rangeland Ecol Manag 63:167-175

Rixon CAM, Duggan IC, Bergeron NMN, Ricciardi A, Macisaac HJ (2005) Invasion risks posed by the aquarium trade and live fish markets on the Laurentian Great Lakes. Biodivers Conserv 14:1365-1381

Roura-Pascual N, Suarez AV, Gomez C, Pons P, Touyama Y, Wild AL, Peterson AT (2004) Geographical potential of Argentine ants (Linepithema humile Mayr) in the face of global climate change. Proc Roy Soc Lond B Biol Sci 271:2527-2534

Rull V, Vegas-Vilarrubia T, Nogue S, Huber O (2009) Conservation of the unique neotropical vascular Flora of the Guayana highlands in the face of global warming. Conserv Biol 23:1323-1327

Sala OE, Chapin FS, Armesto JJ, Berlow E, Bloomfield J, Dirzo R, Huber-Sanwald E, Huenneke LF, Jackson RB, Kinzig A, Leemans R, Lodge DM, Mooney HA, Oesterheld M, Poff NL, Sykes MT, Walker BH, Walker M, Wall DH (2000) Biodiversity - global biodiversity scenarios for the year 2100. Science 287:1770-1774

Saunders A, Norton DA (2001) Ecological restoration at Mainland Islands in New Zealand. Biol Conserv 99:109-119

Schneider SH, Root TL (1996) Ecological implications of climate change will include surprises. Biodivers Conserv 5:1109-1119

Schulze ED, Mollicone D, Achard F, Matteucci G, Federici S, Eva HD, Valentini R (2003) Climate change making deforestation pay under the Kyoto protocol? Science 299:1669-1669

Schwartzman S, Zimmerman B (2005) Conservation alliances with indigenous peoples of the Amazon. Conserv Biol 19:721-727

Secretariat of the Convention on Biological Diversity (2010) Global biodiversity outlook 3. Montreal. http:// www.cbd.int/gbo3/ebook/.

Sekercioglu CH, Schneider SH, Fay JP, Loarie SR (2008) Climate change, elevational range shifts, and bird extinctions. Conserv Biol 22:140-150

Semenza JC, Hall DE, Wilson DJ, Bontempo BD, Sailor DJ, George LA (2008) Public perception of climate change voluntary mitigation and barriers to behavior change. Am J Prev Med 35:479-487

Sessions J, Bettinger P, Buckman R, Newton M, Hamann AJ (2004) Hastening the return of complex forests following fire: the consequences of delay. J For 102:38-45

Shah NJ (2001) Eradication of alien predators in the Seychelles: an example of conservation action on tropical islands. Biodivers Conserv 10:1219-1220

Short J, Smith A (1994) Mammal decline and recovery in Australia. J Mammology 75:288-297

Smit H, Vanderhammen H (1992) Water mites as indicators of natural aquatic ecosystems of the coastal dunes of the netherlands and northwestern France. Hydrobiologia 231:51-64 
Smith SD, Huxman TE, Zitzer SF, Charlet TN, Housman DC, Coleman JS, Fenstermaker LK, Seemann JR, Nowak RS (2000) Elevated CO2 increases productivity and invasive species success in an arid ecosystem. Nature 408:79-82

Snyder WE, Evans EW (2006) Ecological effects of invasive arthropod generalist predators. Annu Rev Ecol Evol Syst 37:95-122

Soulé ME, Mackey BG, Recher HF, Williams JE, Woinarski JCZ, Driscoll D, Dennison WG, Jones ME (2004) The role of connectivity in Australian conservation. Pac Conserv Biol 10:266-279

Spittlehouse DL, Stewart RB (2003) Adaptation to climate change in forest management. Br Columbia J Ecosyst Manag 4:1-11

Steffen W, Burbidge A, Hughes L, Kitching R, Lindenmayer D, Musgrave W, Stafford-Smith M, Werner P (2009) Australia's biodiversity and climate change: a strategic assessment of the vulnerability of Australia's biodiversity to climate change. A report to the Natural Resource Management Ministerial Council commissioned by the Australian Government. CSIRO, Canberra

Strassburg B, Turner RK, Fisher B, Schaeffer R, Lovett A (2009) Reducing emissions from deforestation-the "combined incentives" mechanism and empirical simulations. Global Environ Change Hum Pol Dimens $19: 265-278$

Sutherland WJ, Clout M, Cote IM, Daszak P, Depledge MH, Fellman L, Fleishman E, Garthwaite R, Gibbons DW, De Lurio J, Impey AJ, Lickorish F, Lindenmayer D, Madgwick J, Margerison C, Maynard T, Peck LS, Pretty J, Prior S, Redford KH, Scharlemann JPW, Spalding M, Watkinson AR (2010) A horizon scan of global conservation issues for 2010. Trends Ecol Evol 25:1-7

Swales S, Storey AW, Roderick ID, Figa BS, Bakowa KA, Tenakanai CD (1998) Biological monitoring of the impacts of the Ok Tedi copper mine on fish populations in the Fly River system, Papua New Guinea. Sci Total Environ 214:99-111

Syme GJ, Nancarrow BE, Seligman C (2000) The evaluation of information campaigns to promote voluntary household water conservation. Eval Rev 24:539-578

Taylor CM, Millican DS, Roberts ME, Slack WT (2008) Long-term change to fish assemblages and the flow regime in a southeastern US river system after extensive aquatic ecosystem fragmentation. Ecography 31:787-797

ten Kate K, Bishop J, Bayron R (2004) Biodiversity offsets: views, experience and the business case. IUCN and Insight Investment, London

Theurillat JP, Guisan A (2001) Potential impact of climate change on vegetation in the European Alps: a review. Clim Change 50:77-109

Thomas CD, Ohlemüller R (2009) Climate change and species' distributions: an alien future? In: Perrings C, Mooney H, Williamson M (eds) Bioinvasions and globalization: ecology, economics, management, and policy. Oxford University Press, Oxford

Thomas CD, Cameron A, Green RE, Bakkenes M, Beaumont LJ, Collingham YC, Erasmus BFN, de Siqueira MF, Grainger A, Hannah L, Hughes L, Huntley B, van Jaarsveld AS, Midgley GF, Miles L, Ortega-Huerta MA, Peterson AT, Phillips OL, Williams SE (2004) Extinction risk from climate change. Nature 427:145-148

Thompson JR, Spies TA, Ganio LM (2007) Reburn severity in managed and unmanaged vegetation in a large wildfire. Proc Natl Acad Sci USA 104:10743-10748

Thuiller W, Broennimann O, Hughes G, Alkemade JRM, Midgley GF, Corsi F (2006) Vulnerability of African mammals to anthropogenic climate change under conservative land transformation assumptions. Global Change Biol 12:424-440

Thurow TL, Taylor CA (1999) Viewpoint: the role of drought in range management. J Range Manag 52:413-419

Tilman D (1999) Global environmental impacts of agricultural expansion: the need for sustainable and efficient practices. Proc Natl Acad Sci USA 96:5995-6000

Tomich TP, Thomas DE, van Noordwijk M (2004) Environmental services and land use change in Southeast Asia: from recognition to regulation or reward? Agric Ecosyst Environ 104:229-244

Travis JMJ (2003) Climate change and habitat destruction: a deadly anthropogenic cocktail. Proc Roy Soc Lond Series B Biol Sci 270:467-473

Truscott AM, Soulsby C, Palmer SCF, Newell L, Hulme PE (2006) The dispersal characteristics of the invasive plant Mimulus guttatus and the ecological significance of increased occurrence of high-flow events. J Ecol 94:1080-1091

Tu AT, Beghin J, Gozlan E (2008) Tariff escalation and invasive species damages. Ecol Econ 67:619-629

Tylianakis JM, Didham RK, Bascompte J, Wardle DA (2008) Global change and species interactions in terrestrial ecosystems. Ecol Lett 11:1351-1363

Ureta C, Martorell C (2009) Identifying the impacts of chronic anthropogenic disturbance on two threatened cacti to provide guidelines for population-dynamics restoration. Biol Conserv 142:1992-2001

van der Werf GR, Morton DC, DeFries RS, Olivier JGJ, Kasibhatla PS, Jackson RB, Collatz GJ, Randerson JT (2009) CO2 emissions from forest loss. Nat Geosci 2:737-738 
van Oosterzee P, Preece N, Dale A (2010) Catching the baby: accounting for biodiversity and the ecosystem sector in emissions trading. Conserv Lett 3:83-90

Velez DAT, Del Valle JI (2007) Growth and yield modelling of Acacia mangium in Colombia. New For 34:293-305

Venter O, Laurance WF, Iwamura T, Wilson KA, Fuller RA, Possingham HP (2009) Harnessing carbon payments to protect biodiversity. Science 326:1368-1368

Vitousek PM, Aber JD, Howarth RW, Likens GE, Matson PA, Schindler DW, Schlesinger WH, Tilman GD (1997) Human alteration of the global nitrogen cycle: sources and consequences. Ecol Appl 7:737-750

Vitt P, Havens K, Kramer AT, Sollenberger D, Yates E (2010) Assisted migration of plants: changes in latitudes, changes in attitudes. Biol Conserv 143:18-27

Vos CC, Berry P, Opdam P, Baveco H, Nijhof B, O’Hanley J, Bell C, Kuipers H (2008) Adapting landscapes to climate change: examples of climate-proof ecosystem networks and priority adaptation zones. J Appl Ecol 45:1722-1731

Wake DB, Vredenburg VT (2008) Are we in the midst of the sixth mass extinction? A view from the world of amphibians. Proc Natl Acad Sci USA 105:11466-11473

Walker KF, Thoms MC (1993) Environmental-effects of flow regulation on the lower River Murray, Australia. Regulated Rivers-Research \& Management 8:103-119

Walther G-R, Roques A, Hulme PE, Sykes MT, Pysek P, Kühn I, Zobel M, Bacher S, Botta-Dukát Z, Bugmann H, Czúcz B, Dauber J, Hickler T, Jarosík V, Kenis M, Klotz S, Minchin D, Moora M, Nentwig W, Ott J, Panov VE, Reineking B, Robinet C, Semenchenko V, Solarz W, Thuiller W, Vilà M, Vohland K, Settele J (2009) Alien species in a warmer world: risks and opportunities. Trends Ecol Evol 24:686-693

Ward NL, Masters GJ (2007) Linking climate change and species invasion: an illustration using insect herbivores. Global Change Biol 13:1605-1615

Westoby M, Burgman M (2006) Climate change as a threatening process. Austral Ecol 31:549-550

Whitfield AK (2004) Fishes and freshwater in southern African estuaries - a review. Edp Sciences S A, London, pp 275-289

Whittington RJ, Chong R (2007) Global trade in ornamental fish from an Australian perspective: the case for revised import risk analysis and management strategies. Prev Vet Med 81:92-116

Williams AAJ, Karoly DJ, Tapper N (2001) The sensitivity of Australian fire danger to climate change. Clim Change 49:171-191

Williams SE, Bolitho EE, Fox S (2003) Climate change in Australian tropical rainforests: an impending environmental catastrophe. Proc Roy Soc Lond B Biol Sci 270:1887-1892

Woinarski JCZ, Williams RJ, Price O, Rankmore B (2005) Landscapes without boundaries: wildlife and their environments in northern Australia. Wildl Res 32:377-388

Xu HG, Ding H, Li MY, Qiang S, Guo JY, Han ZM, Huang ZG, Sun HY, He SP, Wu HR, Wan FH (2006) The distribution and economic losses of alien species invasion to China. Biol Invasions 8:1495-1500

Yarnell RW, Scott DM, Chimimba CT, Metcalfe DJ (2007) Untangling the roles of fire, grazing and rainfall on small mammal communities in grassland ecosystems. Oecologia 154:387-402

Yates CJ, Norton DA, Hobbs RJ (2000) Grazing effects on plant cover, soil and microclimate in fragmented woodlands in south-western Australia: implications for restoration. Aust Ecol 25:36-47

Zapiola ML, Campbell CK, Butler MD, Mallory-Smith CA (2008) Escape and establishment of transgenic glyphosate-resistant creeping bentgrass Agrostis stolonifera in Oregon, USA: a 4-year study. J Appl Ecol 45:486-494

Zhao QJ, Wen ZM (2010) Potential analysis and policy innovation of forestry carbon sequestration market under the clean development mechanism in China. Proceedings of the First Global Forum of Ecological Economics in Forestry: 234-243 